\title{
Ab ovo - medical and humanistic deliberations on health
}

\author{
Grażyna Jarząbek-Bielecka' ${ }^{1}$ Małgorzata Mizgier², Magdalena Pisarska-Krawczyk², \\ Paulina Wojtyła-Buciora ${ }^{3,5}$
}

'Clinic of Gynecology of Department of Perinatology and Gynecology, Division of Developmental Gynecology and Sexuology of Department of Perinatology and Gynecology, University of Medical Sciences, Poznan, Poland ${ }^{2}$ Division of Nutrition, Department of Hygiene and Human Nutrition, University of Life Sciences, Poznan, Poland ${ }^{3}$ Higher Vocational State School in Kalisz, Poland

${ }^{4}$ Department of Maternal and Child Health, University of Medical Sciences, Poznan, Poland

${ }^{5}$ Department of Physiology, University of Medical Sciences, Poznan, Poland

\begin{abstract}
The meaning of the Latin term $A b$ ovo is 'from the egg' or 'from the very beginning', and it originates from the proverb ab ovo ad mala, literally 'from the egg to apples', i.e. 'from the beginning to the end'; as meals for ancient Romans started with eggs and ended with apples as a dessert. Within this perspective, the authors have now addressed key aspects of health right from the very beginnings of a human's life.
\end{abstract}

KEY WORDS: health, medicine, philosophy.

ADDRESS FOR CORRESPONDENCE: Magdalena Pisarska-Krawczyk, Higher Vocational State School in Kalisz, 4 Nowy Świat Street, 62-800 Kalisz, Poland, e-mail: magmp@op.pl

\section{INTRODUCTION}

One of mankind's fundamental aspirations is its health. Every culture makes enormous/strenuous efforts to assure a person's health and wellbeing. Both such aspirations assume that as human life is so fragile, it can be successfully improved upon [1].

Furthermore, aspiring to a healthy life is a good way of creatively modifying our given state of health from birth onwards, i.e. at Ab ovo; 'from the egg' $[1,2]$.

\section{STUDY AIM}

To promote both physical and mental health taking into account healthy lifestyles, physical activity, but above all else, diet (by literally promoting the nutritional value of eggs). The egg concept also embraces aspects of fertility and sexuality, and thereby our article includes medical issues of concern to the sciences of the reproductive system.

\section{METHODOLOGY}

An analysis of the literature on health.

\section{DISCUSSION}

If there exist any ways possible to increase the collective wisdom and skills of mankind, they should be sought for in medicine.

Descartes

In the quest for health, mankind has sought to adopt creative interventions in this field. Although many people declare that health is a number one priority, their chosen lifestyles are nonetheless quite the opposite. Over many ages people have, however, pondered about what health actually is and its value. This has been witnessed in the works of the precursors to medical practitioners and philosophers. Modern-day man seeks to find the motivation for the daily caring for one's wellbeing through health [2]. There exist many mechanisms in the human psyche that affect lifestyle; such as the diet. A lot of people fail to see the link between the development of disease and lifestyle and nutrition, where a doctor's proscribed medication is perceived as a means for being healthy. Others, however, even when recognising such a link, are for various reasons unable to alter their lifestyle to one of being pro-health. 
It appears that not only are genes passed down through the generations, but also family traditions and habits. The second nature thus inherited is so deeply ingrained that a person succumbs without even realising. Many health problems like circulatory disorders, overweight, and obesity arise from physiological processes becoming disrupted, processes which over many thousands of years have helped mankind to survive. There is a strong relationship between man and the environment. From the dawn of history, life has been dependent on the rhythms of mother nature. Modern science has, however, elucidated those factors that determine human health. A healthy lifestyle decisively affords health protection (by over $50 \%$ ) thereby showing that persons, by themselves, can be largely responsible for their own health $[2,3]$. Healthy lifestyles are shaped by many behaviours, habits, and attitudes that protect and improve health. The principles governing a healthy lifestyle include healthy and rational nutrition, appropriate physical activity, coping with stress, sufficient sleeping time, absence of harmful addictions (e.g. nicotine, alcohol, drugs, medicines, and other substances), and maintaining an appropriate body mass.

Health is one of those values that specifically affect a person's quality of life. Maintaining health and multiplying its potential constitutes one of the most important challenges facing each individual. The World Health Organisation (WHO) defines health as a state of complete physical, mental, and social well-being and not merely the absence of disease or infirmity. Such a holistic approach places health amongst other factors shaping human life - of the physical, mental, emotional, social, and of the spiritual. Promoting healthy lifestyles and engaging in preventative medicine are actions possessing the largest reserves for maintaining and enhancing health.

$A b$ ovo... An appropriate lifestyle, which includes an adequately balanced diet during pregnancy, affects both the mother's health and foetal development. Conversely, inappropriate diets may lead to congenital malformations as well as chronic disease in children.

Ab ovo... A healthy lifestyle from an early age ensures normal development of mental, physical, and health faculties, and the actions undertaken, choices made, and acquired habits at a young age most commonly determine behaviour throughout later life (Fig. 1).

Dietetics is the scientific discipline that specialises in applying rational nutrition to humans under healthy and diseased conditions. It is concerned with assessing the effects of disease on a patient's nutritional status and the effects of nutrition on treatment outcomes. According to the WHO and $A b$ ovo, egg protein is the gold standard against which other animal- or plant-derived proteins found in foodstuffs are compared, because of the high biological value of eggs. This arises from the fact that egg protein constitutes an invaluable source of exogenous essential amino acids, i.e. those that the body is unable to synthesise and which must therefore be delivered via the diet [4]. In ancient times, the egg was significant in three respects: as a symbol of the world, symbols of the aforementioned fertility and life renewal, along with being a cult object [1]. The term $A b$ ovo also lends itself to humanistic considerations, particularly because nowadays there is an ever-increasing need felt in our culture for a basic reconciliation and joining between the natural sciences and humanities, which medicine can provide. Indeed, it is medicine that connects together scientific studies on humans with their deeply rooted values/value systems. Medicine is thus a means of resolving the tension between the abstract and reality and between the natural sciences and the humanities, together with the search for knowledge, wellbeing, and health. Health also concerns the ability to fulfil roles in society, adapting to changes in the environment, and then coping with such changes [2].

In 1945, Henry Siegerst introduced the concept of Health Promotion, which should be taken as being one of the four main pillars of medicine, along with disease prevention, treatment, and rehabilitation. Within health promotion and protection, one finds subject areas such as physical activity, rational nutrition, maintaining bodily and environmental hygiene, health safety, coping with stress, and undertaking preventative medical testing in areas like gynaecology, andrology, sexology, etc. Health promotion should also be considered from the aspect of sexual health. According to the WHO, this is an integrated state of physical/biological, emotional, mental, and social well-being in relation to sexuality important for the beneficial development of personality, inter-personal communication, and love. Health promotion enables individuals and society groups to increase their control/ empowerment over the factors determining health, leading to its improvement as well as for developing healthy lifestyles and shaping other environmental and individual conditions that are conducive to health.

Sexual issues/problems are present throughout a person's life; from childhood, adolescence, adulthood, and the fading away during old age. The Sexuality Informa-

\section{Factors affecting human development}

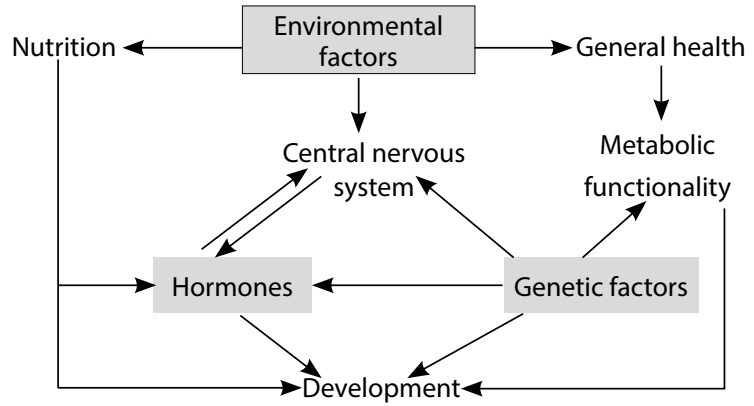

FIG. 1. Key factors affecting human development in health promotion 
tion and Education Council of the United States specifically emphasises the importance of sexual health during adolescence. The psychological perspective on human sexuality is chiefly focused on explaining the role played by emotions and feelings in creating and managing people's sexual behaviour. The scientific study of human sexuality, i.e. sexology, deals with the consequences of having two separate genders and is inextricably linked to sexual ethics, gynaecology (female reproductive system science) and andrology (male reproductive system science). Human sexuality belongs to the sphere of emotions and behaviour whose biological aims are sexual intercourse. Sexuality modifies all of human social behaviour. The development of sexuality to the full is vital for achieving wellbeing at the levels of the individual, interpersonal, and societal [5-7].

\section{CONCLUSIONS}

Thus summarising, the greatest significance and influence on health (including sexual health) is through adopting a pro-healthy lifestyle, i.e. when conscious efforts are made to maintain and protect health right from the very start... 'ab ovo'.

\section{DISCLOSURE}

Authors report no conflict of interest.

\section{References}

1. Pellegrino ED, Thomasma DC. A philosophical basis of medical practice: toward a philosophy and ethic of the healing professions. Oxford University Press, New York 1981.

2. Gloger Z. Encyklopedia staropolska. Hasło „Ab ovo”. Vol. 1. Warszawa 1900. Available from: https://pl.wikisource.org/wiki/ Encyklopedia_staropolska/Ca\%C5\%82o\%C5\%9B\%C4\%87/ Tom_I (accesed: 12 April 2017).

3. Mizgier M, Jarząbek-Bielecka G, Marcinkowska E, et al. Dietary intervention or vitamin and mineral supplementation during pregnancy? Pielęg Pol 2016; 4: 546-555.

4. Gołąb K, Warwas M. Białka jaja kurzego - właściwości biochemiczne i zastosowania [Chicken egg white proteins - biochemical properities and applications]. Adv Clin Exp Med 2005; 14: 1001-1010.

5. Jarząbek-Bielecka G. Health promotion, ethics and legal aspects in adolescents gynecology and sexology. Arch Perinat Med 2016; 22: 39-42.

6. Jarząbek-Bielecka G, Buks J, Mizgier M, et al. The role of diet and physical activity in the prevention of sexual dysfunction associated with the problem of diabetes, metabolic syndrome, polycystic ovary syndrome. Pol Prz Nauk Zdr 2016; 3: 263-268.

7. Jarząbek-Bielecka G, Mizgier M, Wilczak M, et al. Metabolic syndrome, hypothyroidism and depression at consultation: a case history. J Health Inequal 2017; 2: 89-91.

\section{AUTHORS' CONTRIBUTIONS}

GJB, MM, MPK prepared the research concept, collected data, wrote the article. PW collected data and critically reviewed the publication. All authors approved the final version of the article. 